\title{
THE BEHAVIOUR OF POLYDORA CILIATA (JOHNST.). TUBE-BUILDING AND BURROWING
}

\author{
By D. A. DorseTt \\ Department of Zoology, Queen Mary College, London*
}

(Text-figs. I-IO)

Polydora ciliata (Johnst.) is a common but inconspicuous polychaete which burrows in a variety of rocks varying in hardness from the Devonian limestone found at Plymouth to the softer chalk of the Isle of Wight and the London clay at Whitstable on the north Kent coast. It can be a troublesome pest of oysters (McIntosh, 1908; Lunz, I94I; Korringa, 195I), perforating the shell with its galleries. All these materials contain calcium carbonate, the worms being apparently unable to penetrate granites and silicious rocks not containing this substance. McIntosh (1915) found worms burrowing in the noncalcareous shales at St Andrews and I have found them in wooden piles along the Kent coast.

No recent account exists in the literature of either the anatomy or biology of $P$. ciliata. Many of the earlier accounts (Dalyell, I853; McIntosh, 1915) appear to be in need of revision, and knowledge of the feeding and tubebuilding mechanisms, life span, fecundity and growth rates is fragmentary.

\section{The burrow}

The burrow (Fig. IA) is a U-shaped cavity in the substratum, the central part being filled with a partition of loose material cemented together by a mucous secretion of the worm. Under a dissecting microscope this partition usually presents a layered appearance. In burrows in pure limestone the central partition is usually made up of silt and other debris accumulated from outside the burrow, but in clay it contains sand grains and particles of silt which may represent material eroded by the worm in the process of burrowing. The layered appearance of the central partition may mean that deepening of the burrow occurs only at certain times, each thin layer representing a mucous cover over the recently excavated material.

The two limbs of the burrow are lined by a tube composed of mucus and fine sand particles, and this has a smooth mucus lining (Fig. I B). The tube, which projects above the substratum to a height of $0.5 \mathrm{~mm}$, is complete but for a small section at the bottom of the burrow where deepening occurs. In

\footnotetext{
* Present address: Department of Zoology, University College, Ibadan, Nigeria.
} 
the laboratory the worms can build up their tubes to a height of $3 \mathrm{~mm}$ but this does not happen on the shore, the tubes being eroded by wave action.

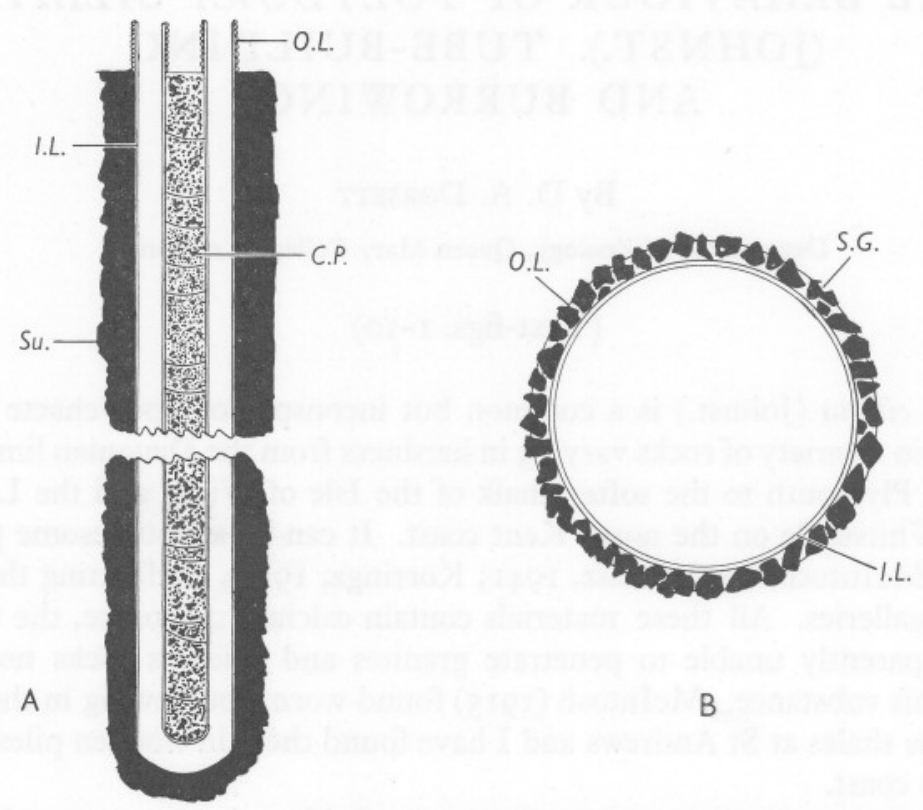

Fig. I. Polydora ciliata. A, Longitudinal section of burrow. B, Transverse section of tube. C.P., central partition; I.L., inner lining; O.L., outer layer; S.G., sand grain; Su., substratum.

\section{Collection of material}

Whilst tube-building $P$. ciliata lies with its head just visible inside the rim of the tube. The palps emerge from the tube and are applied to the substratum with the ciliated groove downwards. This differs from the position adopted when feeding, the palps then performing lashing movements by which particles suspended in the water are collected. The palps are a pair of tapering cylindrical structures arising from the dorsal side of the peristomium. Along their inner surface is a ciliated groove (Fig. 2) which runs from the distal end of the palp to a short distance from the proximal end. The cilia beat towards the head and particles of both food and tube-building material are caught up by them and wound into a mucus string. The tips of the palps are forced among the bottom debris and sand grains are dislodged and carried posteriorly toward the mouth. The ciliated groove ends short of the base of the palp and the mucus string is forced out and met by the prostomium which bends towards it. The string is picked up by the densely ciliated ventral epithelium of the prostomium (Fig. 3, cil.ep.) and is carried towards the mouth.

As the ventral ciliated epithelium of the prostomium passes into the peristomial region it develops a ciliated fold on each side of the median ridge 
(Fig. 4A-E). The outer edges of the epithelium are joined to the inner edges of the lateral lips and in the posterior peristomial region, where the lips meet and join mid-ventrally to form the mouth, the non-ciliated epithelium of the lips still connects the edges of the lateral ciliated folds to form the floor of the anterior part of the gut. Thus, from the mouth to the second segment, the

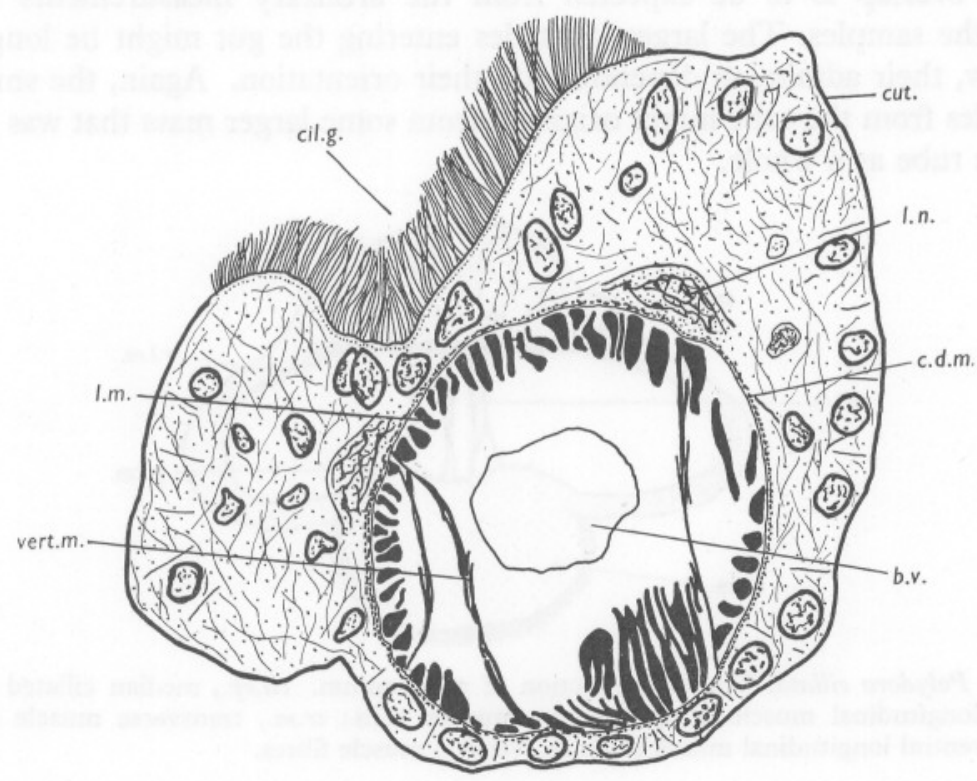

Fig. 2. Polydora ciliata. Transverse section of palp. b.v., blood vessel; cil.g., ciliated groove; c.d.m., circular and diagonal muscle fibres; cut., cuticle; l.m., longitudinal muscle; l.n., longitudinal nerve; vert.m., vertical muscle fibres.

floor of the gut is occupied by a non-ciliated gutter (Fig. 4E). Observations of the worm when tube building show that material is diverted between the lips into the region of the non-ciliated gutter, whereas when feeding, particles pass unhindered down the gut.

There is some indication that $P$. lignii has the ability to distinguish particles by their chemical nature (Mortensen \& Galtsoff, 1944) but the constant presence of small sand grains in the gut of $P$. ciliata suggests that the size of the particle might form the basis on which selection of material for tube building or food is made. To test this a group of $P$. ciliata were removed intact in their tubes from the shore to the laboratory and their faecal pellets were allowed to accumulate. These were then removed and the largest linear dimensions taken from a sample of 200 sand grains. The dimensions of a similar sample of diatom frustules were also taken. The worms were allowed to build up their tubes until they projected some $3 \mathrm{~mm}$ above the surface of the clay. The projecting tubes were then cut off and boiled in caustic potash 
to remove the mucoprotein binding the grains together. The linear dimensions of a similarly sized sample of sand grains was taken from the tubes.

It can be seen (Fig. 5) that the majority of particles passing through the gut are not above $0.03 \mathrm{~mm}$ whilst those used in construction of the tube are mostly above $0.05 \mathrm{~mm}$. Selection usually occurs between these two limits. Some overlap is to be expected from the arbitrary measurements taken from the samples. The largest particles entering the gut might be long and narrow, their admission depending on their orientation. Again, the smallest particles from the tube might originate from some larger mass that was stuck on the tube as a whole.

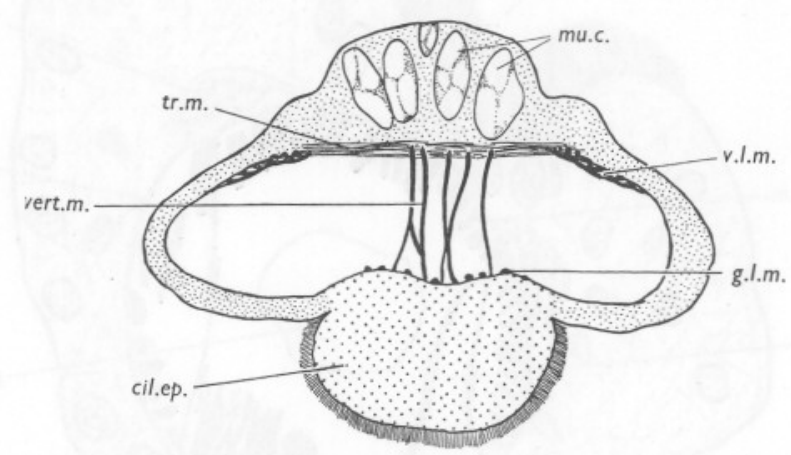

Fig. 3. Polydora ciliata. Transverse section of prostomium. cil.ep., median ciliated ridge; g.l.m., longitudinal muscle of gut; mu.c., mucous cells; tr.m., transverse muscle fibres; v.l.m., ventral longitudinal muscle; vert.m., vertical muscle fibres.

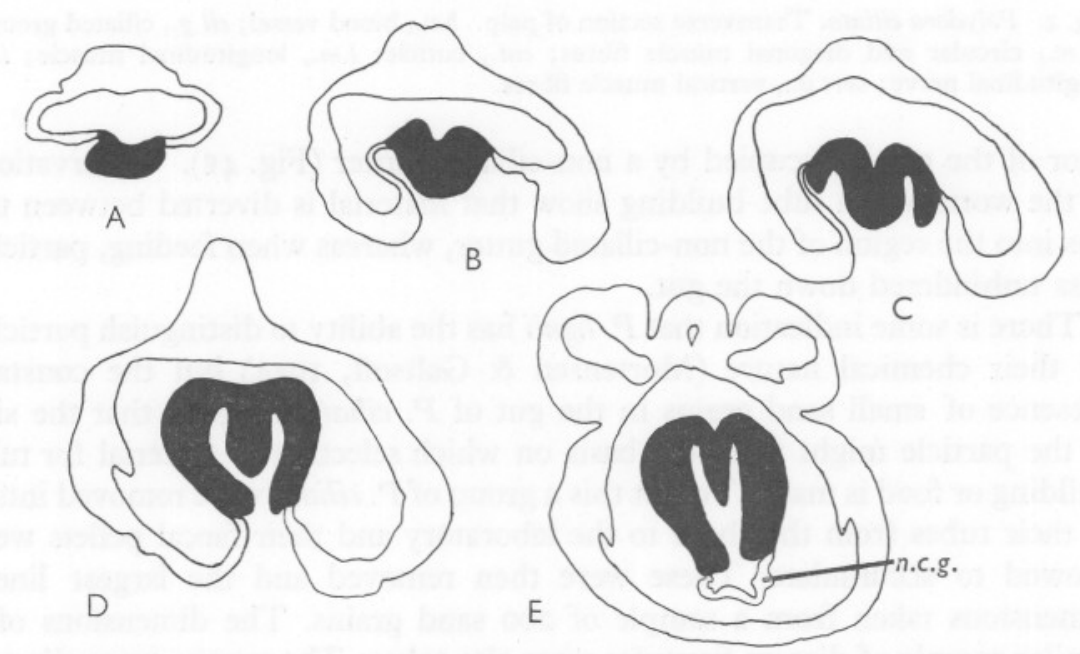

Fig. 4. Polydora ciliata. A-E. Camera lucida drawings of sections taken at progressively posterior levels through the prostomium and peristomium. Ciliated epithelium, black. n.c.g., non-ciliated gutter. 
A mechanism of particle selection is suggested in Fig. 7 A-E. At the point where the lateral ciliated folds are given off from the median ridge on the ventral side of the peristomium, particles too large to pass between the lateral fold and the median ridge would be forced to travel along the outer edge of the ciliated epithelium and would end up in the non-ciliated gutter. Those small enough to pass between the folds would pass unhindered down the gut. Such a mechanism would allow particles collected by the palps to be

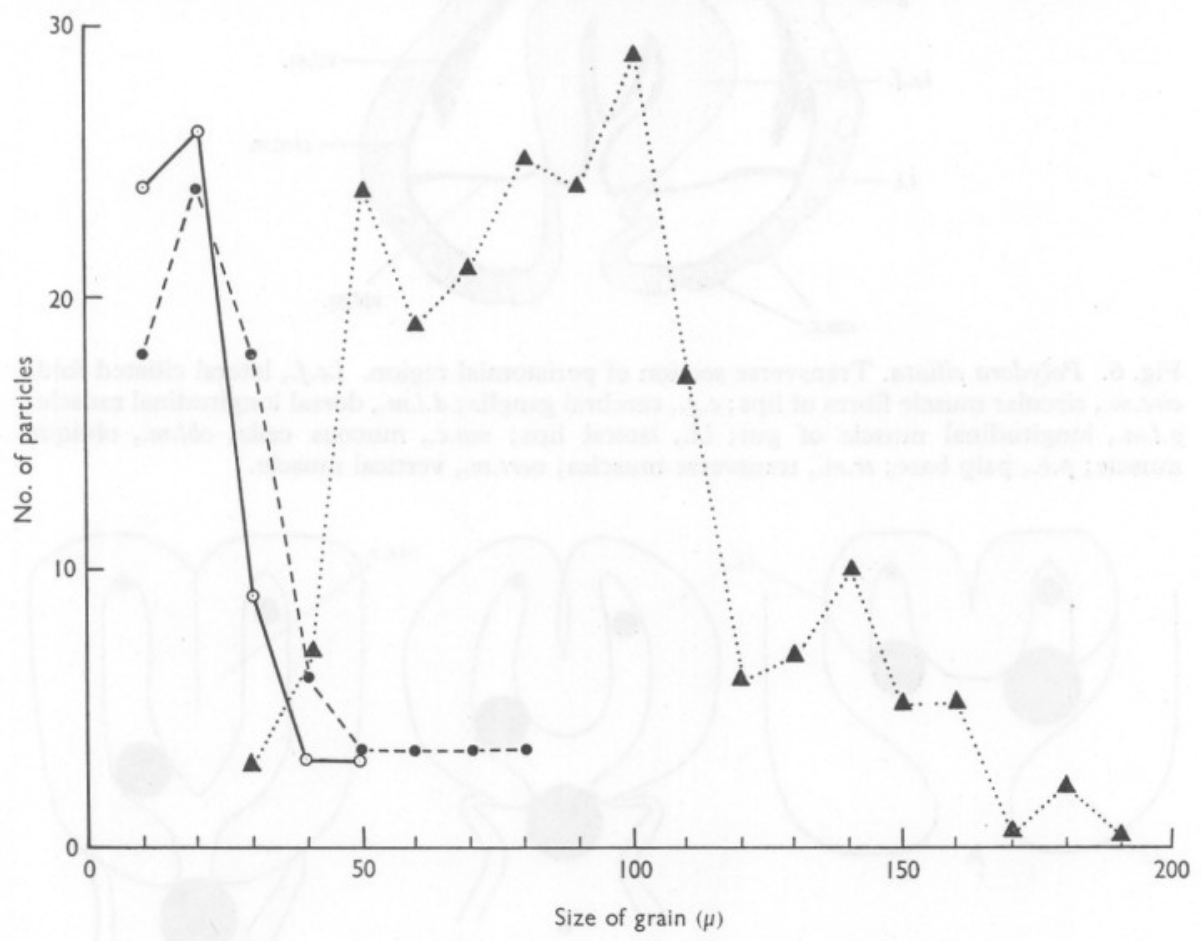

Fig. 5. Polydora ciliata. Analysis of sand grains and diatom frustules from tube and faeces. Continuous line, sand from gut; broken line, diatoms from gut; dotted line, sand from tube.

sorted into two size groups by a mechanism somewhat similar to that described for Sabella pavonina (Nicol, I93I). In this species they are sorted into three size groups between the inclined walls of the gill folds. The finest particles are passed direct to the mouth whilst the medium sized particles are used in the construction of the tube. The largest particles are rejected.

Observations on particle selection are difficult to make and narcotized animals examined under the microscope do not accept particles introduced on to the palps since the mobility of the prostomium is an essential part of the collecting process. Sections of the worms used in the selection experiments were cut and stained. The specimens were first narcotized and then fixed in 


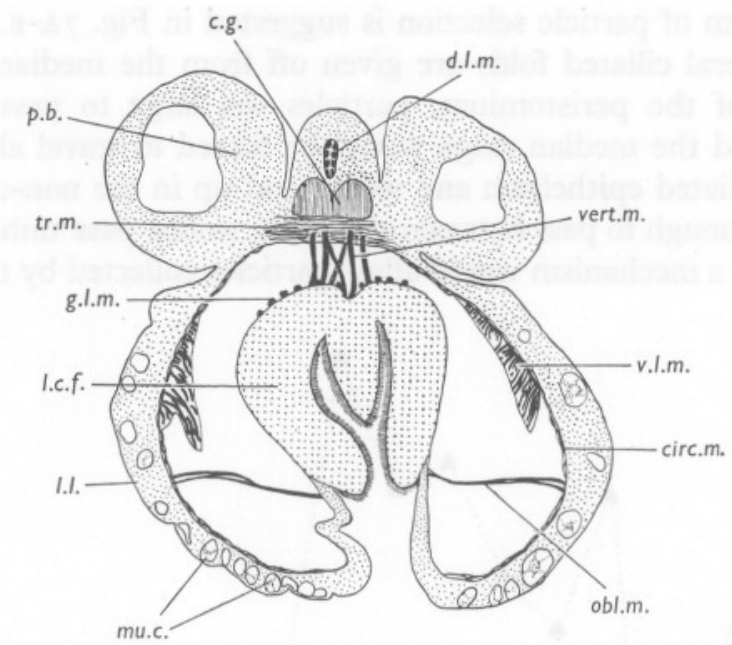

Fig. 6. Polydora ciliata. Transverse section of peristomial region. l.c.f., lateral ciliated fold; circ.m., circular muscle fibres of lips; c.g., cerebral ganglia; d.l.m., dorsal longitudinal muscle; g.l.m., longitudinal muscle of gut; l.l., lateral lips; mu.c., mucous cells; obl.m., oblique muscle; p.b., palp base; tr.m., transverse muscles; vert.m., vertical muscle.

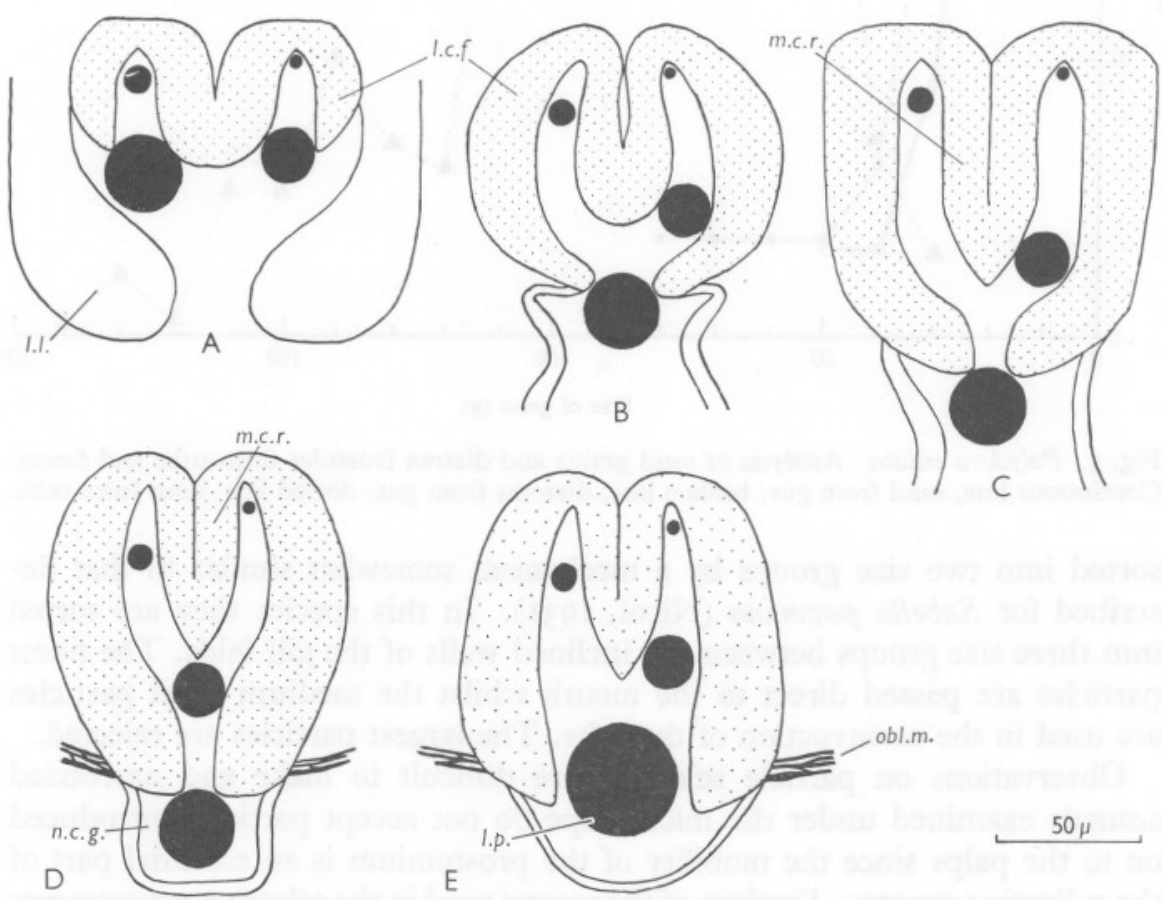

Fig. 7. Polydora ciliata. Suggested particle selection mechanism. l.l., lateral lips; l.c.f., lateral ciliated folds; l.p., large particle; m.c.r., median ciliated ridge; n.c.g., non-ciliated gutter; obl.m., oblique muscle. 
Gilson's fluid. In this way shrinkage was kept to a minimum. The distance between the lateral ciliated folds and the median ridge, which is critical in deciding the point where separation of the two groups of particles is made, was measured and found to be $0.032 \mathrm{~mm}$. This corresponds closely to the size at which division is made in nature.

In the laboratory worms will accept food particles larger than those taken under normal conditions. Examination of the muscular anatomy of the peristomium shows how this might be achieved. Contraction of the oblique muscle (Fig. 6, obl.m.) which crosses the coelomic cavity of the lateral lips to the edge of the ciliated epithelium, and relaxation of the vertical muscle fibres which pass from the dorsal body wall to their insertion above the median ridge, against a positive pressure of the coelomic fluid, would allow the groove between the ciliated epithelia to widen and a larger sized particle to be accepted (Fig. $7 \mathrm{E}$ ).

\section{Construction of the tube}

In the normal pattern of behaviour, tube-building alternates with periods of feeding. In the laboratory, tube-building behaviour can be initiated by adding a suspension of clay particles to the water artificially circulating in the dish. It may also occur spontaneously in worms living in filtered sea water that is not in movement. Under these conditions the animals eventually become quiescent except for intermittent excursions to the mouth of the tube to sample the water.

When adding material to the tube the worm crawls forward until its head emerges from the end. The lateral lips then diverge and the sand grains, which have been diverted into the non-ciliated gutter (see above), are pushed forward between them (Fig. 8A). The worm then bends its head towards the side of the tube and the sand grain is placed on the rim. It then retreats into the tube only to re-emerge immediately and cement the grain more firmly in position, pressing the ventral body wall of the first and second segments over the region where the sand grain was placed. The epithelium of both the lips and the ventral body wall contains large mucous cells which cover the grains with a layer of secretion. The mucus hardens rapidly in sea water and fixes them securely. The pressing may be repeated a second time. The worm retreats into the tube whilst more material is collected by the palps and the cycle is then repeated. In subsequent cycles, before placing more material on the rim of the tube, the body is rotated through a small angle so that the grains are placed by the side of those deposited in the previous cycle. The direction of turn appears to be constant in any one phase of tube-building activity but may differ in following phases. In this way the tube is built up evenly on all sides.

The worm emerges from the tube until the seventh chaetigerous segment is just visible, the body is held quite straight with the palps in front of the 
head and immobile (Fig. 8B). The worm then rotates its body through $360^{\circ}$ about its longitudinal axis, first in one direction and then in the other. Whilst it is turning, the notopodial chaetae are protracted and retracted in a 'treading' motion against the wall of the tube. This treading activity is frequently followed by four rapid protrusions of the head from the tube,

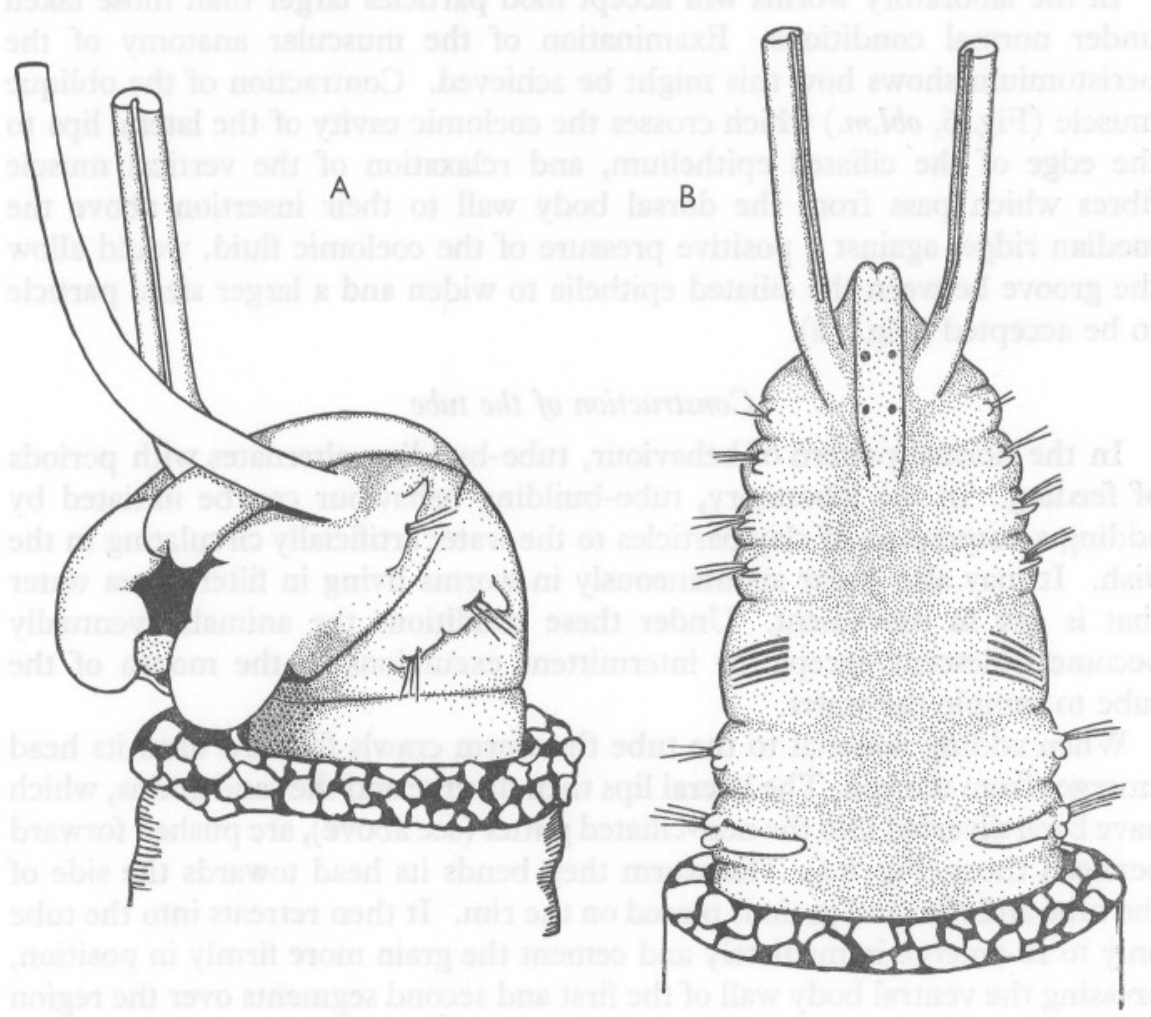

Fig. 8. Polydora ciliata. A, Placing sand grain on rim of tube. B, Tube lining position.

identical to those in which a sand grain is being placed but no grain being deposited. Between each excursion the body is turned through one right angle so that all four sides of the rim are touched in turn by the lateral lips. In this way the worm probably senses any irregularity of the rim of the tube.

The significance of this last pattern of activity becomes clear when one examines the structure of the tube and the anatomy of the thoracic segments. It is in the seventh segment that the segmental mucus glands, the 'poches glandulaires' of Fauvel (1927), first appear. These glands (Fig. 9, s.m.g.) are found protruding into the ventral coelom in a variable number of segments after and including the seventh. Each gland consists of six or seven large 
mucous cells so closely apposed as to resemble a single transparent vesicle. From each cell an intra-cellular duct passes behind the neuropodial chaetae to emerge on the ventro-lateral body wall in a small papilla. There are a group of the papillae on each side of the mid-line in each segment that bears the glands.

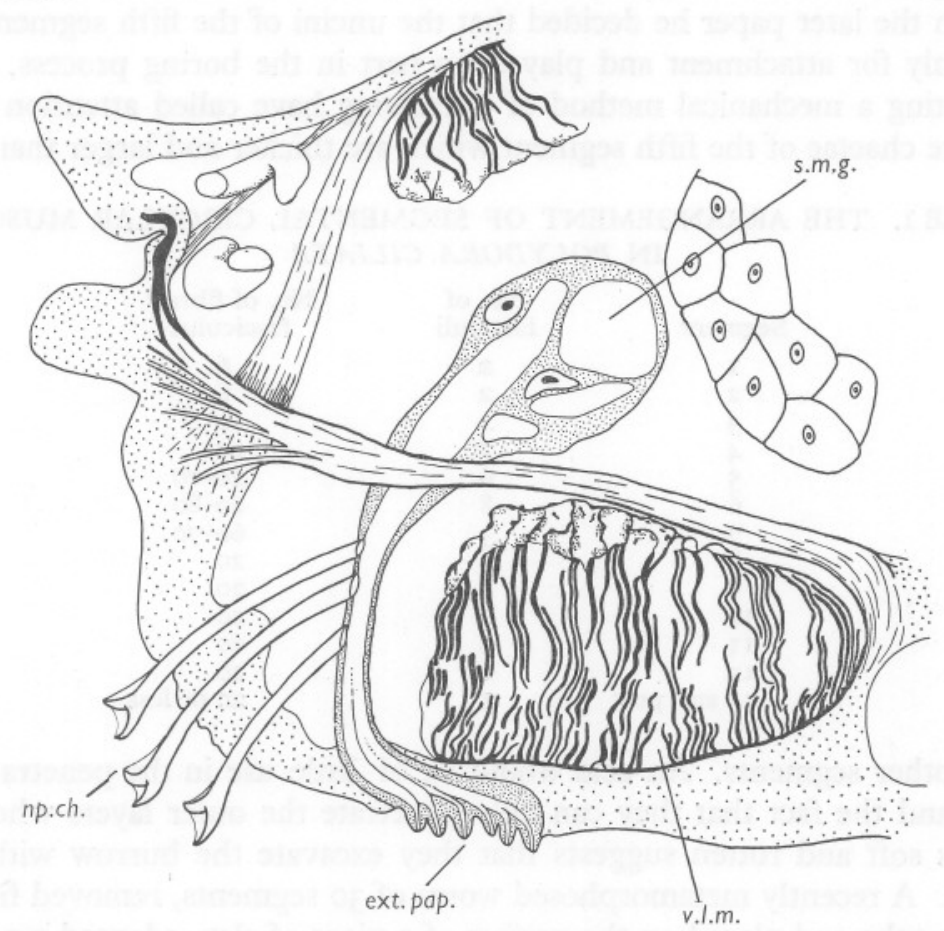

Fig. 9. Polydora ciliata. Transverse section of trunk segment posterior to branchia. ext.pap., external papillae of gland; $n p . c h$., neuropodial chaetae; s.m.g., segmental mucus gland; v.l.m., ventral longitudinal muscle.

It seems that after the worm has added a new length to the tube, the inner lining is still rough. The worm then emerges as far as the seventh segment and rotates its body, spreading the secretion of the segmental mucus glands on the unlined portion of its tube and working it into the outer layers with its chaetae. The secretion hardens rapidly in sea water, forming the inner lining to the tube. The staining reactions of the segmental mucus glands and tube lining with alcian blue suggest an acid mucopolysaccharide similar to that identified in the glands and tubes of other polychaetes (Ewer \& Hanson, 1945).

\section{Excavation of the burrow}

Theories invoking both chemical solution and mechanical abrasion have been advanced to account for the method by which $P$. ciliata penetrates its 
various substrates. Chemical penetration was thought to be achieved by means of an acid secretion which would dissolve calcium carbonate, but no acid has yet been identified in polychaetes. Söderström (1920, 1923) at first considered that boring was effected by an acid secretion of the segmental mucus glands combined with the mechanical action of the chaetae of segment five. In the later paper he decided that the uncini of the fifth segment were used only for attachment and played no part in the boring process. Those postulating a mechanical method of burrowing have called attention to the uncinate chaetae of the fifth segment which are thicker and larger than those

TABLE 1. THE ARRANGEMENT OF SEGMENTAL CIRCULAR MUSCLES IN POLYDORA CILIATA

$\begin{array}{ccc}\text { Segment } & \begin{array}{c}\text { No. of } \\ \text { fasciculi }\end{array} & \begin{array}{c}\text { No. of fibres/ } \\ \text { fasciculus }\end{array} \\ \text { I } & 2 & 6 \\ 2 & 2 & 6 \\ 3 & 2 & \text { I2 } \\ 4 & 2 & 20 \\ 5 & 6 & 20-70 \\ 6 & 8 & 20-80 \\ 7 & 3 & 60-70 \\ 8 & 3 & 20 \\ 9 & 3 & 20 \\ \text { I0 } & 2 & 20 \\ \text { II } & 2 & 20 \\ \text { I2 } & 2 & 20 \\ \text { I3 and post } & 1 & 20 \text { or less }\end{array}$

of the other segments. An acid would be of little use in the penetration of wood, and the fact that they can only penetrate the outer layers where the wood is soft and rotten suggests that they excavate the burrow with their chaetae. A recently metamorphosed worm of 30 segments, removed from its primary tube and placed on the surface of a piece of clay, adopted a position in which the chaetae on one side of the fifth segment were used as a fixed point whilst those of the other side were flexed ventrally and then flicked violently upward (see similar observation of a newly settled worm in Wilson, 1928, pp. 583-4). This is essentially the movement that would be used in mechanical excavation of the burrow and was observed to dislodge some small sand grains from the surface. The entire musculature of the fifth segment, apart from the longitudinal muscles, is devoted to producing a dorso-ventral movement of the chaetae. The dorsal circular muscle fibres (Fig. Io, d.lev.m.) are inserted on the dorsal border of the chaetal sac where it meets the body wall, and its action is reinforced by the dorsal circular muscles of segments six and seven which pass forwards to the same insertion. The circular muscles of Polydora ciliata resemble those of the errant polychaetes in being drawn together dorsally in each segment into fasciculi. It can be seen from Table I that both the number of fasciculi and the number of fibres in each fasciculus is greater in segments five, six and seven than in any other segment. 
The chaetae of the fifth segment are not used in normal locomotory movements and the nature of the muscle supply together with the orientation of the chaetae in the sac points to the fact that they are entirely devoted to producing a powerful upward flick.

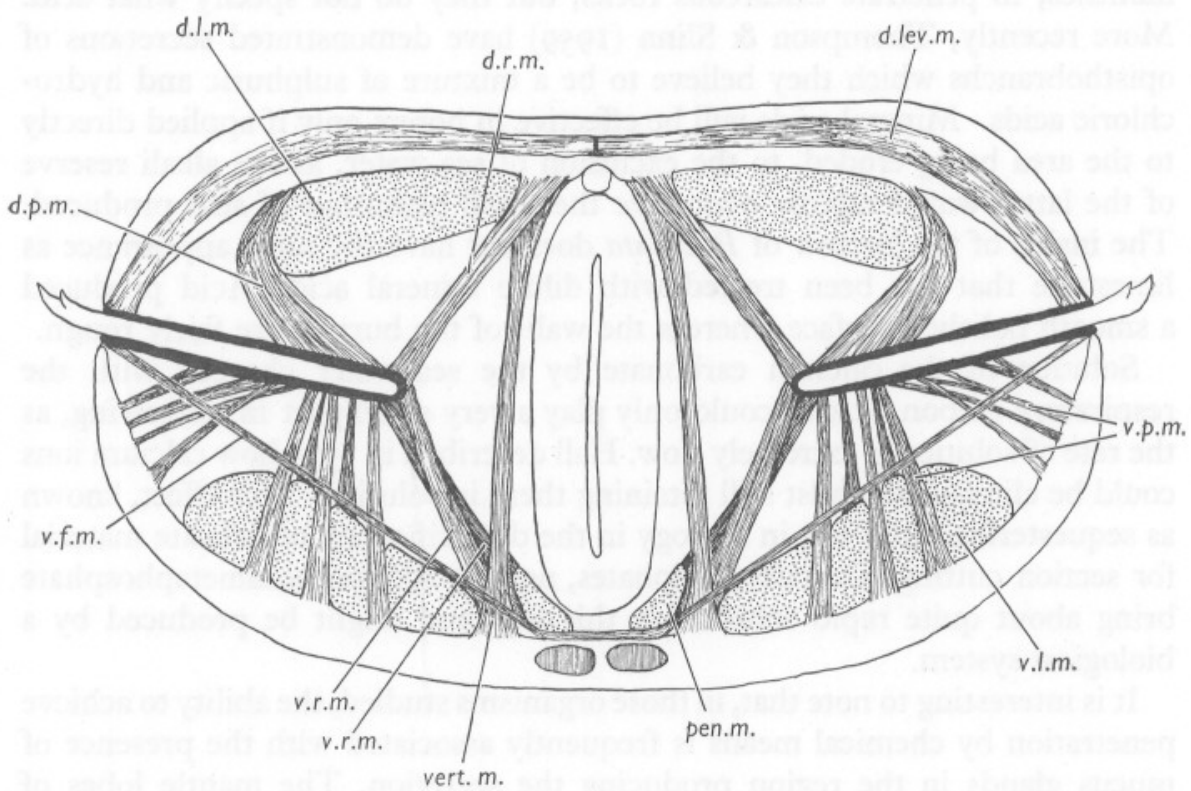

Fig. Io. Polydora ciliata. Transverse section of fifth segment showing muscle supply to uncini. d.lev.m., dorsal levator muscle; d.l.m., dorsal longitudinal muscle; d.p.m., dorsal protractor muscle; d.r.m., dorsal retractor muscles; pen.m., pennate muscles; vert.m., vertical muscles; v.f.m., ventral flexor muscle; v.l.m., ventral longitudinal muscle; v.p.m., ventral protractor muscle; v.r.m., ventral retractor muscle.

On the other hand, it seems unlikely that the relatively delicate chaetae of Polydora could produce cavities $26 \times 3 \times 1 \mathrm{~mm}$ in hard limestone. In order to test (rather simply) the effect of mechanical abrasion by a chaeta, a neuropodial chaeta of Aphrodite aculeata was mounted vertically against a block of limestone and rotated at $85 \mathrm{rev} / \mathrm{min}$ for $\mathrm{II} 2 \mathrm{~h}$ under a pressure of $\mathrm{IO} \mathrm{g}$. At the end the rock showed no sign of abrasion though the chaeta was shorter by $0.04 \mathrm{~mm}$. Such evidence suggests that the tanned protein which forms the chaetae of polychaetes (Ebling, I945) is too soft a material to be alone responsible for the excavation of the burrow in limestone. Comparison of the tips of the uncini of the worms boring in clay at Whitstable with those boring in limestone at Plymouth shows that whilst those of the Plymouth worms are a little more rounded there is comparatively little more wear. Possibly the galleries in limestone are occupied and deepened by succeeding generations, but this does not occur at Whitstable where old burrows are rapidly filled in. 
Though it seems that $P$. ciliata in fact penetrates some materials by the mechanical action of the chaetae, yet the penetration of limestone must still be accounted for. Several authors (List, 1902; Russell-Hunter, 1949; Yonge, I955) suggest the presence of an acid secretion to assist organisms, particularly molluscs, to penetrate calcareous rocks, but they do not specify what acid. More recently, Thompson \& Slinn (1959) have demonstrated secretions of opisthobranchs which they believe to be a mixture of sulphuric and hydrochloric acids. Mineral acids will be effective in borers only if applied directly to the area being eroded, to the exclusion of sea water, as the alkali reserve of the latter would rapidly neutralize the small quantities of acid produced. The inside of the burrow of $P$. ciliata does not have the same appearance as limestone that has been treated with dilute mineral acid. Acid produced a smooth polished surface whereas the walls of the burrow are fairly rough.

Solution of the calcium carbonate by the sea water charged with the respiratory carbon dioxide could only play a very small part in burrowing, as the rate of solution is extremely slow. Hall described in 1935 how calcium ions could be eliminated whilst still retaining them in solution. This effect, known as sequestering, finds use in zoology in the decalcification of delicate material for section cutting. Certain phosphates, notably sodium hexametaphosphate bring about quite rapid solution in this way and might be produced by a biological system.

It is interesting to note that, in those organisms studied, the ability to achieve penetration by chemical means is frequently associated with the presence of mucus glands in the region producing the secretion. The mantle lobes of Hiatella (see Russell-Hunter, 1949) and Lithophaga (see Yonge, 1955) both have glands giving a mucous-staining reaction in the region producing the chemical solvent. The ventral epithelium and segmental mucus glands of $P$. ciliata have an abundance of cells staining with alcian blue, which indicates an acid mucopolysaccharide. Simkiss \& Tyler (1958) have demonstrated how acid mucopolysaccharides in the spongy layer of the egg shell of the hen may act as a chelating agent for metallic ions, calcium in particular. There seems no reason to suppose that the mucous secretions of $P$. ciliata and other rock-boring organisms could not behave in a similar way to bring about solution of calcareous substrates.

I should like to record my thanks to Prof. J. E. Smith, F.R.S., for his advice and criticism in all stages of this work, to Prof. G. E. Newell and Prof. J. E. Webb for reading the typescript, and to the Director of the Marine Biological Association for facilities afforded whilst I was working at the Plymouth Laboratory. 


\section{SUMMARY}

Polydora ciliata is a spionid polychaete found below mid-tidal level burrowing in a variety of rocks all of which contain calcium carbonate. It can also penetrate some non-calcareous materials such as rotten wood. It excavates a $U$-shaped burrow which it lines with a tube composed of mucoprotein and sand grains. This tube has a smooth inner lining of mucoprotein. Both food and tube-building material is collected by the palps and it is suggested that discrimination is made chiefly on size of the particle. Selection is made between the limits of $0.03-0.05 \mathrm{~mm}$, the smaller particles passing down the gut whilst the larger are used in construction of the tube. A particle selection mechanism is suggested. The function of the segmental mucus glands is to provide the inner lining of the tube.

The problem of chemical penetration of rocks by animals is discussed. $P$. ciliata uses both mechanical and chemical methods. No acid has been identified, and the use of a sequestering or chelating agent linked with the biochemistry of mucus is suggested.

Since preparing this paper for the press, my attention has been drawn to a paper by Hempel (1957). In a general account of the morphology and tubebuilding of four members of the genus Polydora and Pygospio elegans, she describes the collection of food and tube-building material in Polydora ciliata. Her observations are in agreement with my own, although she does not analyse the tube-building behaviour in detail. She found that sand grains between 0.2 and $0.05 \mathrm{~mm}$ were preferred in constructing the tube, but concludes that the texture and weight are more important than the size of the particle. She did not examine the contents of the faecal pellets for inorganic particles, the presence of which suggests that size is the principal factor in selection. In a survey of the types of substratum chosen by $P$. ciliata in which to burrow, she found that in the molluscan shell the calcite layer is preferred to the aragonite layer because of its softer nature. Boring, which in the recently metamorphosed worm may be assisted by an acid secretion, is thought in the adult worm to be achieved by the mechanical action of the uncinate chaetae of the fifth segment. Evidence for this is principally in the presence of scratches on the wall of the burrow and wear on the chaetae, but again no attempt was made to determine the degree of hardness of the chaetae with respect to the material they erode.

\section{REFERENCES}

Dalyell, J. G., I853. Powers of the Creator. London: John van Voorst.

EBLING, F. J., I945. Formation and nature of the opercular chaetae of Sabellaria. Quart. F. micr. Sci., Vol. 85, pp. I53-76.

EWER, D. W. \& HANSON, J., 1945. Some staining reactions of invertebrate mucoproteins. F. R. micr. Soc., Vol. 65, pp. 40-3. 
Fauvel, P., 1927. Polychètes sédentaires. Faune Fr., No. I6, 494 pp.

HEMPEL, C., I957. Úber den Rohrenbau und die Nahrungsaufnahme einiger spioniden der deutschen Küsten. Helgoländ. wiss. Meeresunters., Bd. 6, Heft. I, pp. I00-134.

Korringa, P., I951. The shell of Ostrea edulis as a habitat. Arch. Zool., Vol. ro, pp. 32-152.

LIst, T., I902. Die Mytiliden. Fauna u. Flora Neapel, Mon. 27.

Lunz, G. R., I94I. Polydora, a pest in S. Carolina oysters. F. Elisha Mitchell. sci. Soc., Vol. 57 (2), pp. 273-83.

McIntosh, W. C., 1908. On the perforation of marine animals. Zoologist, Ser. 4, Vol. I2, pp. 4I-60.

1915. British Marine Annelids. London: Ray Society.

MORTENSEN, E. \& GALTSOFF, P., I944. Behaviour and tube building habits of Polydora lignii. Biol. Bull. Woods Hole, Vol. 87, pp. 164-5.

Nicol, E. A. T., I93I. Feeding mechanism, formation of the tube, and physiology of digestion in Sabella pavonina. Trans. roy. Soc. Edinb., Vol. 56, pp. 537-89.

RuSSELl-HUNTER, W., 1949. Structure and behaviour of Hiatella gallicana and $H$. arctica. Proc. roy. Soc. Edinb., Vol. 63, pp. 271-89.

Simkiss, K., \& TYLER, C., I958. The organic matrix of hen egg shells. Quart. F. micr. Sci., Vol. 98, pp. 19-28.

SöDERStröm, A., 1920. Studien über die Polychaetenfamilie Spionidae. Uppsala. Inaug. Diss. Almquist and Wicksells.

- 1923. Über das Bohren der Polydora. Zool. Bidrag. Uppsala, Vol. 8.

Thompson, T. E. \& Sinn, P., 1959. On the biology of Pleurobranchus membranaceus. F. mar. biol. Ass. U.K., Vol. 38, pp. 507-24.

WILson, D. P., 1928. The larvae of P. ciliata and P. hoplura. F. mar. biol. Ass. U.K., Vol. I5, pp. 567-89.

YONGE, C. M., 1955. Adaptation to boring in Botula and Lithophaga. Quart. F. micr. Sci., Vol. 96, pp. 383-410. 